\title{
ANALISA AERODINAMIKA AIRFOIL NACA 0021 DENGAN ANSYS FLUENT
}

\author{
M. Fajri Hidayat \\ Program Studi Teknik Mesin, Fakultas Teknik \\ Universitas 17 Agustus 1945 Jakarta \\ Email : fajri17845@gmail.com
}

\begin{abstract}
ABSTRAK
Analisa performa aerodinamika suatu penampang airfoil sangatlah diperlukan untuk menerntukan gaya angkat maksimum yang terjadi serta gaya-gaya yang bekerja pada penampang airfoil seperti Gaya Drag dan Gaya Lift. Dalam penelitian ini suatu desain penampang airfoil seri NACA 0021 suatu airfoil simetris di test dengan menggunakan software ANSYS Fluent dengan input kecepatan, viskositas dan densitas fluida sehingga dapat diketahui sebaran kecepatan dan sebaran tekanan di sepanjang airfoil. Untuk mendapatkan performa yang maksimal dari airfoil ini, diberi variasi sudut serang yang berbeda-beda sehingga nantinya di dapatkan sudut serang maksimal untuk menghasilkan gaya angkat yang maksimal juga. Dari kontur kecepatan dan kontur tekanan yang terbaca di ANSYS Fluent sepanjang permukaan atas dan permukaan bawah airfoil diambil harga rataratanya dan kemudian di plot dalam grafik untuk menunjukkan besarnya gaya lift dan gaya drag yang terjadi serta dari distribusi kecepatan dan distribusi temperatur tersebut diperoleh harga koefisien drag dan koefisien lift. Penelitian ini diharapkan bisa bermanfaat di dunia aerodinamika khususnya yang berhubungan dengan sayap pesawat sehingga permodelan ini bisa memaksimalkan performa terbang suatu pesawat dan memungkinkan pengembangan desain sayap-sayap pesawat yang sesuai dengan pemilihan desain totalnya dengan standarstandar NACA.
\end{abstract}

Keywords : Aerodinamika, Airfoil, Sudut Serang, Gaya angkat

\section{PENDAHULUAN}

Dalam dunia kedirgantaraan telah banyak penelitian dan riset mengenai sayap pesawat terbang baik itu dengan metode eksperimental dengan menggunakan model di dalam wind tunnel, metode perhitungan dan analisa dengan rumus dan persamaan aerodinamika yang ada dan akhir-akhir ini penelitian mengenai dunia aeromodeling me ngutup pada metode komputerisasi dengan CFD (Computational Fluid Dynamics) baik itu menggunakan software-software terpakai misalnya CFDSof, Solid Work maupun dengan software yang lebih khusus yaitu ANSYS Fluent.

Trend riset ke arah komputerisasi dengan CFD ini dikarenakan pesatnya perkembangan software-software program di bidang engineering khususnya mengenail dinamika fluida dan dikarenakan juga oleh para periset tidak mau dipusingkan dengan metode-metode perhitungan 
Pemilihan design pesawat terbang sangat ditentukan oleh aplikasi di lapangan oleh karenanya dalam pemilihan design ini telah banyak standarisasi yang dilakukan salah satunya adalah dengan airfoil seri NACA. Dalam riset kali ini dipilih NACA seri 4 digit yaitu NACA 0021 .

Adapun dalam riset ini bertujuan untuk mengetahui pengaruh perubahan sudut serang $(\alpha)$ airfoil terhadap distribusi kecepatan dan distribusi tekanan begitu juga pengaruhnya terhadap koefisien lift $\left(\mathrm{C}_{\mathrm{L}}\right)$ dan koefisien drag $\left(\mathrm{C}_{\mathrm{D}}\right)$. Pengambilan variasi sudut serang yang dipakai yaitu $0^{\circ}, 3^{\circ}, 6^{\circ}, 9^{\circ}, 12^{\circ}$ dan $15^{\circ}$

Dengan tujuan yang lebih khusus lagi yaitu untuk mendapatkan gaya angkat maksimum (Lift) yang terjadi pada sudut serang tertentu $(\alpha)$.

\section{TINJAUAN PUSTAKA}

\section{Mekanisme Pesawat Untuk Te rbang}

Ada beberapa macam gaya yang bekerja pada benda-benda yang terbang di udara. Gaya-gaya aerodinamika ini meliputi gaya angkat (lift), gaya dorong (thrust), gaya berat (weight), dan gaya hambat udara (drag).

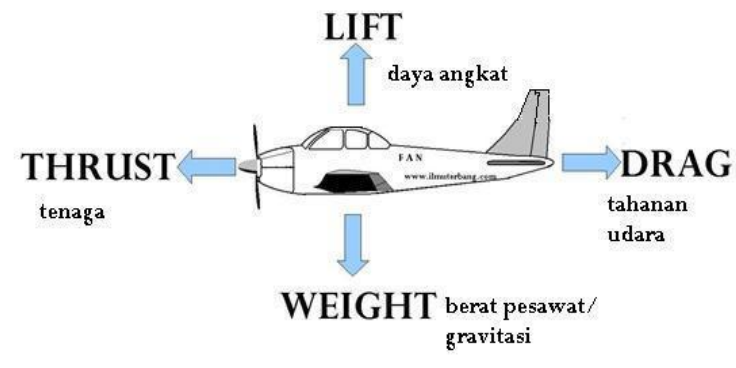

Gambar 1 Gaya-gaya yang bekerja pada Pesawat

Supaya bisa terbang, kita perlu gaya yang bisa mengatasi gaya berat akibat tarikan gravitasi bumi. Gaya ke atas (lift) ini harus bisa melawan tarikan gravitasi bumi sehingga benda bisa terangkat dan mempertahankan posisinya di angkasa. Di sinilah tantangannya karena harus melawan gravitasi. Maka fisikawan seperti Isaac Newton, Bernoulli, dan Coanda. Ketiganya bekerja sama menjawab tantangan ini.

\section{Hukum Newton III}

Isaac Newton yang terkenal dengan ketiga persamaan geraknya menyumbangkan hukum III Newton tentang Aksi-Reaksi. Benjamin Crowell dalam bukunya Newtonian Physics mengatakan bahwa "ketika objek A memberikan sebuah gaya kepada objek B, maka objek B juga harus memberikan sebuah gaya kepada objek A. Dua gaya tersebut besarnya sama dan dalam arah yang berlawanan. Dan dapat dituliskan secara singkat dengan rumus seperti berikut ini $\mathrm{F}_{\mathrm{A}}$ on $\mathrm{B}=-\mathrm{F}_{\mathrm{B}}$ on $\mathrm{A}$ ". Hukum inilah yang kemudian diterapkan pada kajian tentang aerodinamika pada airfoil sayap pesawat terbang. Sayap pesawat merupakan 
bagian terpenting dalam menghasilkan lift. Aliran udara terjadi diatas dan dibawah sayap pesawat. Partikel-partikel udara menabrak bagian bawah sayap pesawat. Partikel-partikel yang menabrak ini lalu dipantulkan ke bawah (ke arah tanah). Udara yang menghujani tanah ini merupakan gaya aksi. Dan kemudian tanah yang menerima gaya aksi ini pasti langsung memberikan gaya reaksi yang besarnya sama dengan gaya aksi tetapi berlawanan arah.

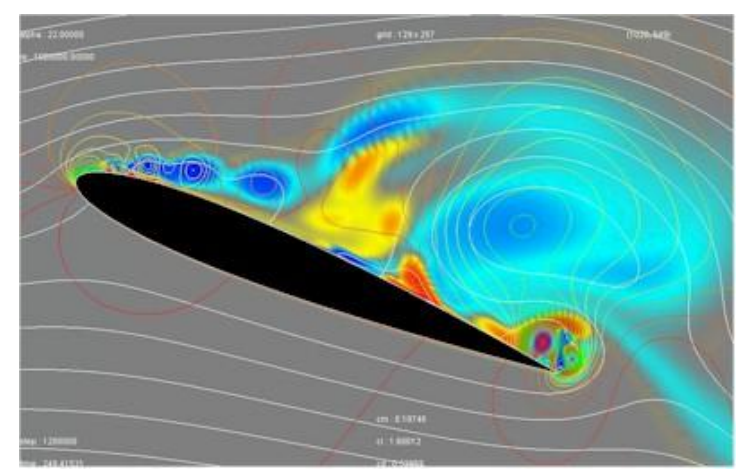

Gambar 2 Arah aliran fluida pada Airfoil

\section{Efek Coanda dan Hukum Bernoulli}

Untuk bagian atas sayap, ada proses lain yang juga menghasilkan aksi. Dalam hal ini terjadi penerapan hukum Bernoulli dan efek Coanda. Menurut Coanda, udara yang melewati permukaan lengkung akan mengalir sepanjang permukaan itu (dikenal sebagai Efek Coanda). Ini dibuktikan ketika kita meletakkan lilin menyala di depan sebuah botol. Ketika lilin ditiup dari belakang botol, aneh ternyata lilin didepan botol itu akan mati. Menurut Coanda hal ini disebabkan karena udara yang kita tiup mengalir mengikuti permuk aan lengkung botol lalu meniup api lilin hingga mati. Seperti inilah udara yang melewati bagian atas sayap ini mirip udara yang bergerak sepanjang botol. Udara ini akan mengalir sepanjang permukaan atas sayap hingga mencapai ujung bawah sayap. Di ujung bawah sayap itu partikel-partikel udara bergerombol dan bertambah terus sampai akhirnya kelebihan berat dan berjatuhan dimana peristiwa ini disebut downwash. Siraman udara atau downwash ini juga merupakan komponen gaya aksi. Tanah yang menerima gaya aksi ini pasti langsung memberikan gaya reaksi yang besarnya sama dengan gaya aksi tetapi berlawanan arah. Karena gaya aksinya menuju tanah (ke arah bawah), berarti gaya reaksinya ke arah atas. Gaya reaksi ini memberikan gaya angkat (lift) yang bisa mengangkat pesawat dan mengalahkan gaya berat akibat tarikan gravitasi bumi. Sumber gaya angkat (lift) yang lain adalah perbedaan tekanan udara dipermukaan atas dan dipermukaan bawah sayap, dimana terjadi penerapan Hukum Bernoulli disini. Untuk aliran inkompresibel, dimana $\rho=$ konstan, persamaan yang terjadi adalah :

$$
P_{1}+\frac{1}{2} \rho V_{1}^{2}=P_{2}+\frac{1}{2} \rho V_{2}^{2}
$$




\section{Airfoil}

Airfoil atau aerofoil adalah suatu bentuk geometri yang apabila ditempatkan di suatu aliran fluida akan memproduksi gaya angkat (lift) lebih besar dari gaya hambat (drag). Pada airfoil terdapat bagian-bagian seperti berikut :

a) Leading Edge adalah bagian yang paling depan dari sebuah airfoil.

b) Trailing Edge adalah bagian yang paling belakang dari sebuah airfoil.

c) Chamber line adalah garis yang membagi sama besar antara permukaan atas dan permukaan bawah dari airfoil mean chamber line.

d) Chord line adalah garis lurus yang menghubungkan leading edge dengan trailing edge.

e) Chord (c) adalah jarak antara leading ed ge dengan trailling edge.

f) Maksimum chamber adalah jarak maksimum antara mean chamber line dan chord line. Posisi maksimum chamber diukur dari leading edge dalam bentuk persentase chord.

g) Maksimum thickness adalah jarak maksimum antara permukaan atas dan permukaan bawah airfoil yang juga diukur tegak lurus terhadap chord line.

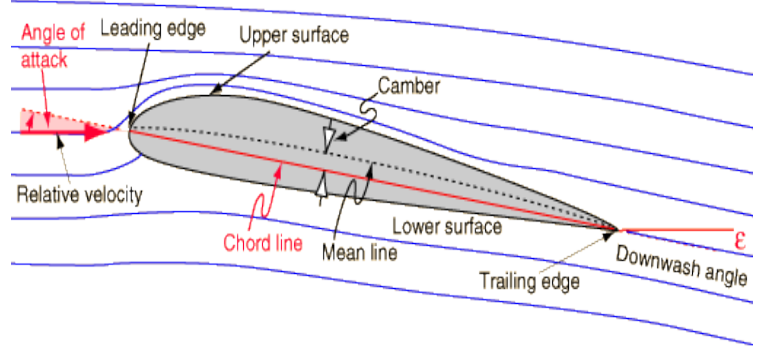

Gambar 3 Bagian-bagian airfoil

\section{Airfoil NACA}

NACA airfoil adalah bentuk airfoil sayap pesawat udara yang dikembangkan oleh National Advisory Committee for Aeronautics (NACA). Sampai sekitar Perang Dunia II, airfoil yang banyak digunakan adalah hasilriset Gottingen. Selama periode ini banyak pengujuan arifoil dilakukan diberbagai negara, namun hasil riset NACA lah yang paling terkemuka. Pengujian yang dilakukan NACA lebih sistematik dengan membagi pengaruh efek kelengkungan dan distribusi ketebalan atau thickness serta pengujiannya dilakukan pada bilangan Reynold yang lebih tinggi dibanding yang lain.

\section{Konstruksi Geometri Airfoil NACA}

Airfoil yang saat ini umum digunakan sangat dipengaruhi oleh hasil penelitian yang dilakukan oleh NACA ini. Dan berikut adalah klasifikasi jenis-jenis airfoil NACA :

\section{NACA Seri 4 Digit}

Pada airfoil NACA seri empat, digit pertama menyatakan persen maksimum chamber terhadap chord. Digit kedua menyatakan persepuluh posisi maksimum chamber pada chord dari leading edge. Sedangkan dua digit terakhir menyatakan persen ketebalan airfoil terhadap 
chord. Contoh : airfoil NACA 2412 memiliki maksimum chamber 0.02 terletak pada $0.4 \mathrm{c}$ dari leading edge dan memiliki ketebalan maksimum $12 \%$ chord atau $0.12 \mathrm{c}$.

\section{NACA Seri 5 Digit}

Jika dibandingkan ketebalan (thickness) dan chamber, seri ini memiliki nilai $\mathrm{C}_{\mathrm{L}}$ maksimum 0.1 hingga 0.2 lebih tinggi dibanding seri empat digit. Sistem penomoran seri lima digit ini berbeda dengan seri empat digit. Pada seri ini, digit pertama dikalikan 3/2 kemudian dibagi sepuluh memberikan nilai desain koefisien lift. Setengah dari dua digit berikutnya merupakan persen posisi maksimum chamber terhadap chord. Dua digit terakhir merupakan persen ketebalan/thickness terhadap chord. Contohnya, airfoil 23012 memiliki $\mathrm{C}_{\mathrm{L}}$ desain 0.3 , posisi maksimum chamber pada $15 \%$ chord dari leading edge dan ketebalan atau thickness sebesar $12 \%$ chord.

\section{NACA Seri-1 (Se ri 16)}

Penamaan airfoil seri 1 ini menggunakan lima angka. Misalnya NACA 16-212. Digit pertama menunjukkan seri 1. Digit kedua menunjukkan persepuluh posisi tekanan minimum terhadap chord. Angka dibelakang tanda hubung : angka pertama merupakan persepuluh desain $C_{L}$ dan dua angka terakhir menunjukkan persen maksimum thickness terhadap chord. Jadi NACA 16-212 artinya airfoil seri 1 dengan lokasi tekanan minimum di 0.6 chord dari leading edge, dengan desain $\mathrm{C}_{\mathrm{L}} 0.2$ dan thickness maksimum 0.12 .

\section{NACA Seri 6.}

Aturan penamaan seri 6 ini cukup membingungkan dibanding seri lain, diantaranya karena adanya banyak perbedaan variasi yang ada. Contoh yang umum digunakan misalnya NACA 641-212, a = 0.6. Angka 6 di digit pertama menunjukkan seri 6 dan menyataan famili ini didesain untuk aliran laminer yang lebih besar dibanding seri 4 digit maupun 5 digit. Angka 4 menunjukkan lokasi tekanan minimum dalam persepuluh terhadap chord ( $0.4 \mathrm{c}$ ). Subskrip 1 mengindikasikan bah range drag minimum dicapai pada 0.1 diatas dan dibawah $\mathrm{C}_{\mathrm{L}}$ design yaitu 2 dilihat angka 2 setelah tanda hubung. Dua angka terakhir merupakan persen thickness terhadap chord, yaitu $12 \%$ atau 0.12 . Sedangkan $a=0,6$ mengindikasikan persen chord airfoil dimana distribusi tekanannya seragam, dalam contoh ini adalah $60 \%$ chord.

\section{NACA Seri 7}

Contohnya adalah NACA 747A315. Angka 7 menunjukkan seri. Angka 4 menunjukkan lokasi tekanan minimum di permukaan atas dalam persepuluh (yaitu 0.4c) dan angka 7 pada digit ketiga menunjukkan lokasi tekanan minimum di permukaan bawah airfoil dalam persepuluh (0.7c). A, sebuah huruf pada digit keempat, menunjukkan suatu format distribusi ketebalan dan mean line yang standardisasinya dari NACA seri awal. Angka 3 pada digit kelima menunjukkan $\mathrm{C}_{\mathrm{L}}$ desain dalam persepuluh (yaitu 0.3) dan dua angka terakhir menunjukkan persen ketebalan maksimum terhadap chord, yaitu $15 \%$ atau 0.15 . 


\section{NACA Seri 8}

Airfiol NACA seri 8 didesain untuk penerbangan dengan kecepatan supercritical. Sistem penamaannya sama dengan seri 7 , hanya saja digit pertamanya adalah 8 yang menunjukkan serinya. Contohnya adalah NACA 835A216 adalah airfoil NACA seri 8 dengan lokasi tekanan minimum di permukaan atas ada pada $0.3 \mathrm{c}$, lokasi tekanan minimum di permukaan bawah ada pada $0.5 \mathrm{c}$, memiliki $\mathrm{C}_{\mathrm{L}}$ desain 2 dan ketebalan atau thickness maksimum 0.16c. 2.5 Sudut Serang (Angle of Attack) Sudut serang adalah sudut yang dibentuk oleh tali busur sebuah airfoil dan arah aliran udara yang melewatinya (relative wind). Biasanya diberi tanda $\alpha$ (alpha). Untuk airfoil simetris, besar lift yang dihasilkan akan nol bila sudut serang nol, sedang pada airfoil tidak simetris sekalipun sudut serang nol tetapi gaya angkat telah timbul. Gaya angkat menjadi nol bila airfoil tidak simetis membentuk sudut negatif terhadap aliran udara. Sudut serang dimana gaya angkat sebesar nol ini disebut zero angle lift.

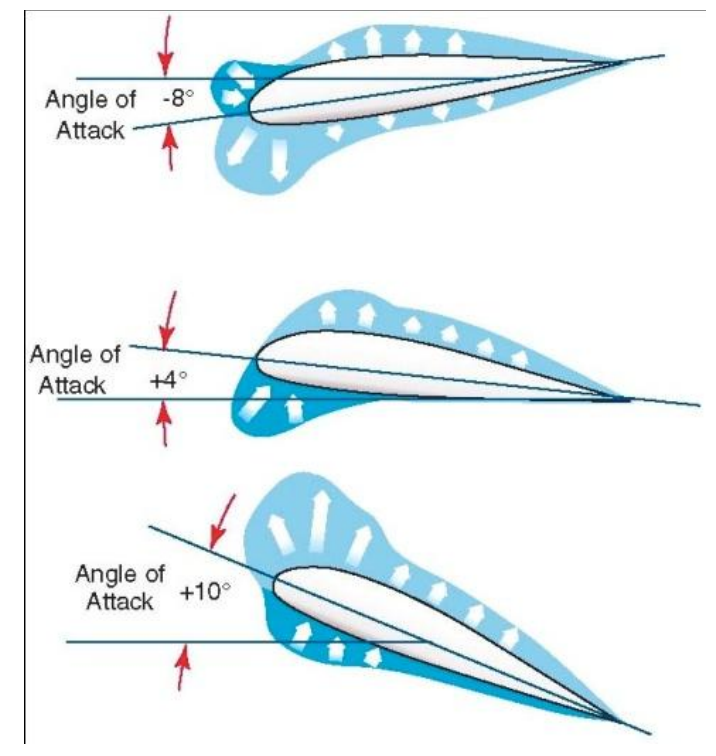

Gambar 4 Angle of attack sebuah Airfoil

\section{METODOLOGI PENELITIAN}

\section{Studi Kasus}

- Identifikasi Masalah Riset yang mengacu pada pengembangan teknologi airfoil sebagai salah satu bagian yang penting dalam dunia aerodinamika telah banyak dilakukan pada tahun-tahun belakangan ini. Hasil dari berbagai eksperimen telah banyak digunakan untuk mendesain airfoil dalam berbagai konfigurasi sayap yang sesuai dengan penggunaannya. Karakteristik airfoil tergantung banyak hal, sehingga dapat dikatakan bah tap airfoil mempunyai penggunaan yang spesifik. Namun hal-hal yang seperti diatas sering diabaikan dalam dunia pesawat terbang model, hal itu disebabkan oleh para penggemar pesawat terbang model tidak ingin dipusingkan oleh perhitungan dan analisa-analisa tentang pesawat. Hal inilah yang mendasari penulis untuk menekankan penelitian ini pada analisa karakteristik 
aerodinamika airfoil NACA 0021 pada sayap pesawat terbang dengan menggunakan software berbasis Computional Fluid Dinamic (CFD).

\section{Variabel terikat}

Dalam penelitian ini di tetapkan variable terikat yakni:

1. Dimensi dan geometri airfoil

2. Properties dari udara

3. Kecepatan pesawat

\section{Variabel bebas}

Variable bebas pada penelitian ini dibatasi pada penentuan sudut serang (angel of attack) dari airfoil.

\section{Spesifikasi Data Airfoil}

Berikut ini adalah data dari airfoil NACA 0021 yang digunakan sebagai objek penelitian :

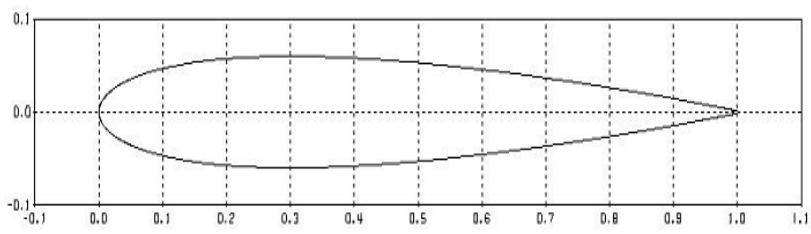

Gambar 5 Penampang Airfoil NACA 0021

\section{Spesifikasi Fluida}

Spesifikasi fluida, dalam hal ini udara juga sangat diperlukan untuk analisis simulasi dalam penelitian ini, berikut ini adalah properties dari udara : - Suhu aktivitas penerbangan (siang hari $)=30,8^{\circ} \mathrm{C}$ (sumber : BPS SUMUT).

Tabel 1 Viskositas Udara

\begin{tabular}{|c|c|}
\hline $\mathbf{T}\left({ }^{\mathbf{0}} \mathbf{C}\right)$ & Viscositas $\left(\mathbf{m}^{\mathbf{2}} / \mathbf{s}\right)$ \\
\hline 0 & $13,27 \times 10^{-6}$ \\
\hline 20 & $15,05 \times 10^{-6}$ \\
\hline $\mathbf{3 0 , 8}$ & $\mathbf{1 6 , 0 6 \times 1 0 ^ { - 6 }}$ \\
\hline 40 & $16,92 \times 10^{-6}$ \\
\hline 60 & $18,86 \times 10^{-6}$ \\
\hline 80 & $20,88 \times 10^{-6}$ \\
\hline 100 & $22,98 \times 10^{-6}$ \\
\hline
\end{tabular}


Tabel 2 Densitas udara

\begin{tabular}{|c|c|}
\hline $\mathbf{T}\left({ }^{\mathbf{0}} \mathbf{C}\right)$ & $\left.\boldsymbol{\rho} \mathbf{( K g} / \mathbf{m}^{\mathbf{3}}\right)$ \\
\hline-25 & 1,423 \\
\hline-20 & 1,395 \\
\hline-15 & 1,368 \\
\hline-10 & 1,342 \\
\hline-5 & 1,316 \\
\hline 0 & 1,293 \\
\hline 5 & 1,269 \\
\hline 10 & 1,247 \\
\hline 15 & 1,225 \\
\hline 20 & 1,204 \\
\hline 25 & 1,184 \\
\hline 30 & 1,164 \\
\hline $\mathbf{3 0 , 8}$ & $\mathbf{1 , 1 6 1}$ \\
\hline 35 & 1,146 \\
\hline
\end{tabular}

\section{Urutan Proses Analisis}

Pengumpulan data awal Pada tahap ini dilakukan pengumpulan data tentang informasi yang berkaitan dengan airfoil NACA 0021 serta spesifikasi data yang dibutuhkan untuk dilakukan penelitian.

\section{Studi literatur}

Penelitian ini harus berlandaskan pada azas azas teoritis yang diakui di dalam dunia keteknikan secara ilmiah sehingga dapat dijadikan rujukan penyelesaian penelitian ini. Studi literatur ini dilakukan dengan cara memperolehnya dari buku buku referensi, jurnal jurnal ilmiah, kumpulan symposium, diskusi personal, atau bahkan lewat media internet. Landasan teoritis ini menyangkut masalah dasar dasar mekanika fluida, dasar-dasar aerodinamika penerbangan, khususnya terhadap pembahasan yang berkaitan dengan airfoil.

\section{Komputasi data}

Data data yang dibutuhkan selam proses pengerjaan di input kedalam proses komputasi data meliputi pemodelan bentuk geometri, simulasi awal untuk memilih jenis airfoil dan sudut serang, kemudian melakukan simulasi kedua dengan memvariasiakan sudut serang untuk memperoleh daftar tabel distribusi tekanan dan kecepatan sehingga dapat dihubungkan antara angle of attack dengan pengaruh tekanan dan kecepatan fluida yang mengalir pada airfoil. 


\section{Pembahasan hasil komputasi data}

Pada tahapan ini akan dilakukan pembahasan terhadap masing-masing hasil simulasi dengan berbagai input variabel bebasnya untuk kemudian dibandingkan hasilnya sehingga didapat performansi yang maksimal yang terjadi pada sudut serang tertentu.

\section{Penarikan kesimpulan}

Penarikan kesimpulan ini berdasarkan korelasi terhadap tujuan penelitian yang telah ditetapkan sebelumnya. Dengan demikian diharapkan tidak terjadi penyimpangan dari tujuan penelitian.

\section{HASIL DAN PEMBAHASAN}

Hasil dari simulasi dalam penelitian ini berupa kontur sebaran tekanan di sekeliling airfoil dan kontur sebaran kecepatan fluida yang mengalir di sekeliling airfoil. Dan juga dapat dilihat gaya-gaya yang terjadi pada airfoil sehingga dapat dihitung nilai $C_{L}$ dan $C_{D}$ dari airfoil NACA 0021 yang diteliti tersebut.

\section{Nilai Bilangan Reynold}

$$
\begin{gathered}
R e=\rho \frac{v L}{\mu} \\
\mu=\vartheta \rho \\
\vartheta=\frac{\mu}{\rho} \\
\vartheta=\text { viskositas }
\end{gathered}
$$

Dimana,

$$
\begin{gathered}
\rho=\text { densitas udara }\left(1,161 \mathrm{~kg} / \mathrm{m}^{3}\right) \\
V=\text { kecepatan pesawat }=16 \mathrm{~m} / \mathrm{s} \\
\mathrm{L}=\text { chord }(\text { lebar sayap })=0,18 \mathrm{~m} \\
\vartheta=\text { viskositas }=16,06 \times 10^{-6} \mathrm{~m}^{2} / \mathrm{s} \\
\text { sehingga, } \\
\operatorname{Re}=\frac{V L}{\vartheta} \\
\operatorname{Re}=\frac{16 \frac{\mathrm{m}}{\mathrm{s}} 0,18 \mathrm{~m}}{16,06 \times 10^{-6} \mathrm{~m}^{2} / \mathrm{s}}=179327,52
\end{gathered}
$$




\section{Hasil Simulasi pada Sudut Serang $0^{\circ}$}

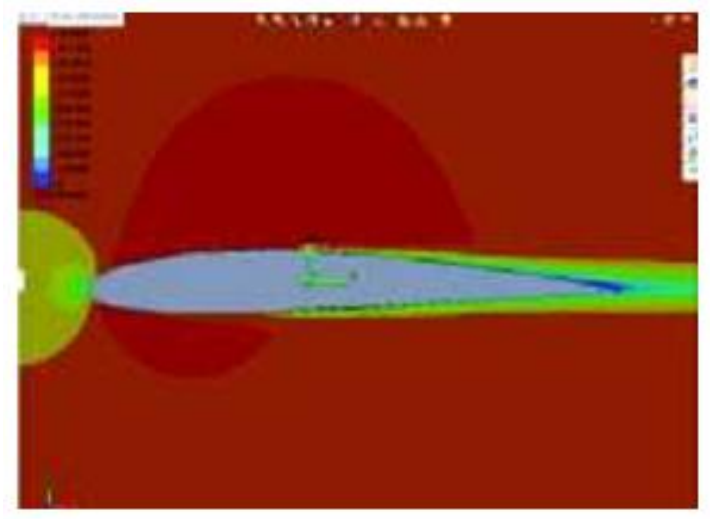

Gambar 6 Kontur sebaran kecepatan pada sudut serang $0^{\circ}$

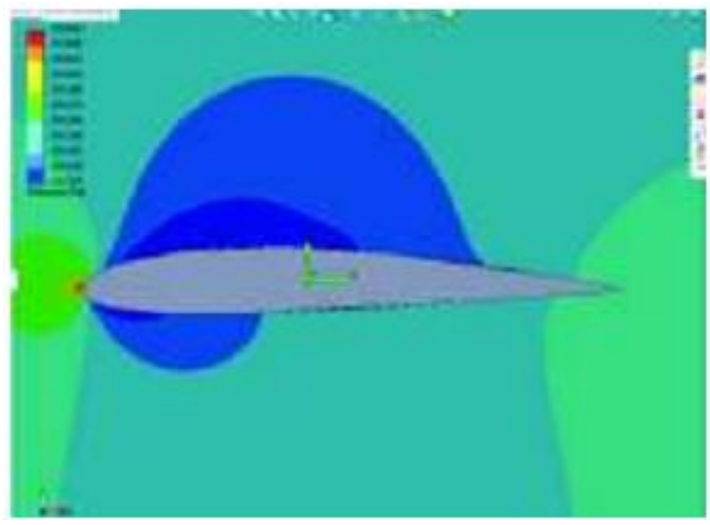

Gambar 7 Kontur sebaran tekanan pada sudut serang $0^{\circ}$

\section{Hasil Simulasi pada Sudut Serang $3^{\circ}$}

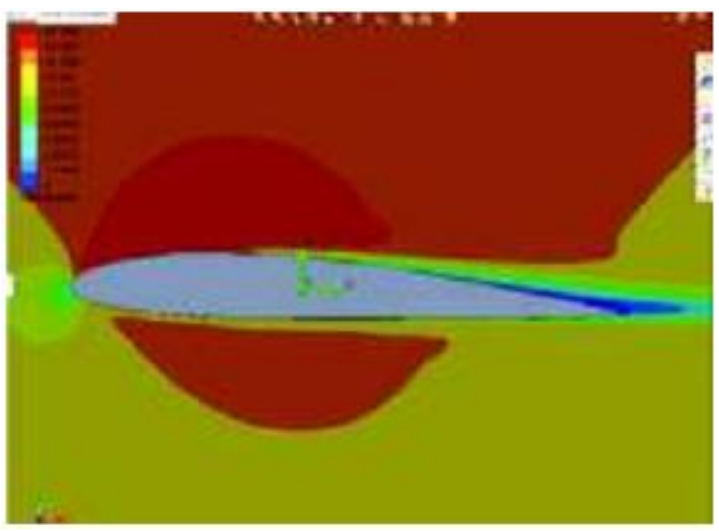

Gambar 8 Kontur sebaran kecepatan pada sudut serang $3^{\circ}$ 


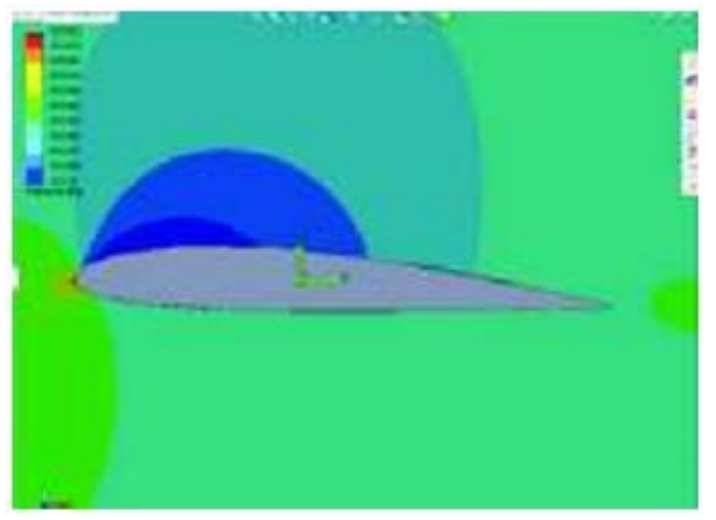

Gambar 9 Kontur sebaran tekanan pada sudut serang $3^{\circ}$

\section{Hasil Simulasi pada Sudut Serang $6^{0}$}

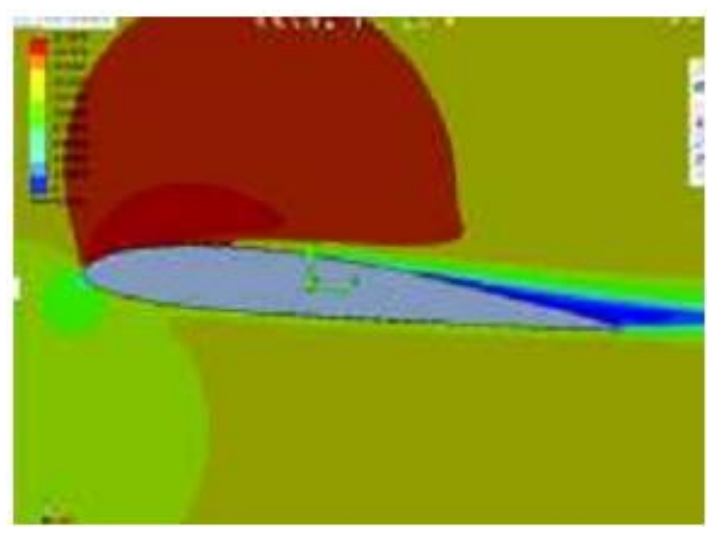

Gambar 10 Kontur sebaran kecepatan pada sudut serang $6^{\circ}$

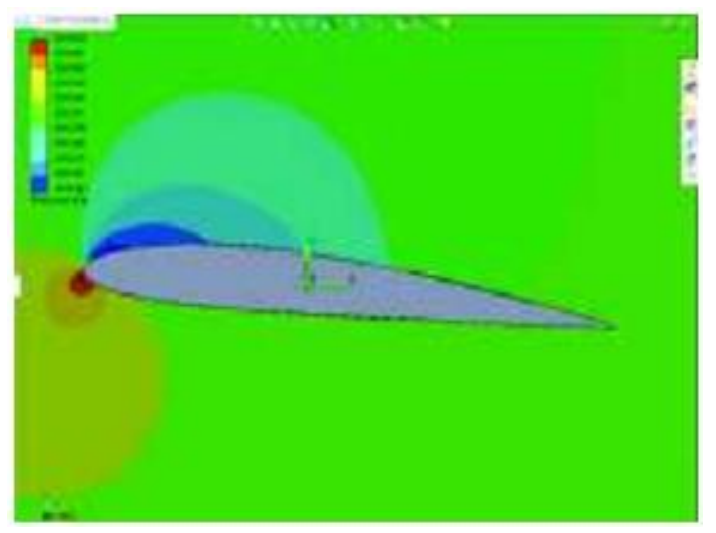

Gambar 11 Kontur sebaran tekanan pada sudut serang $6^{\circ}$ 


\section{Hasil Simulasi pada Sudut Serang $9^{\circ}$}

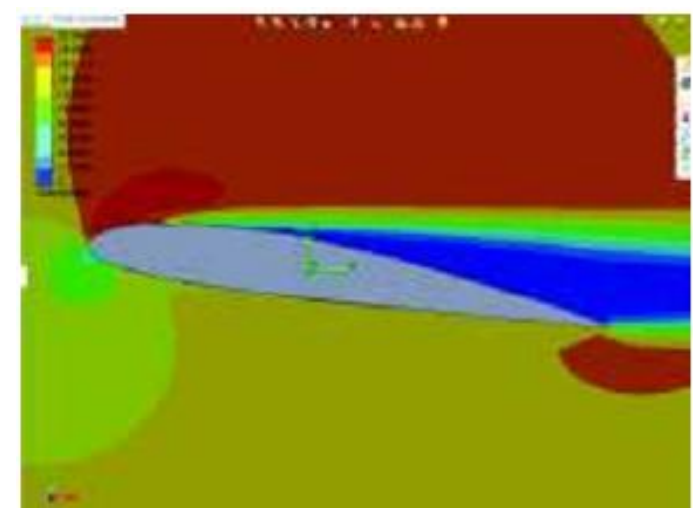

Gambar 12 Kontur sebaran kecepatan pada sudut serang $9^{\circ}$

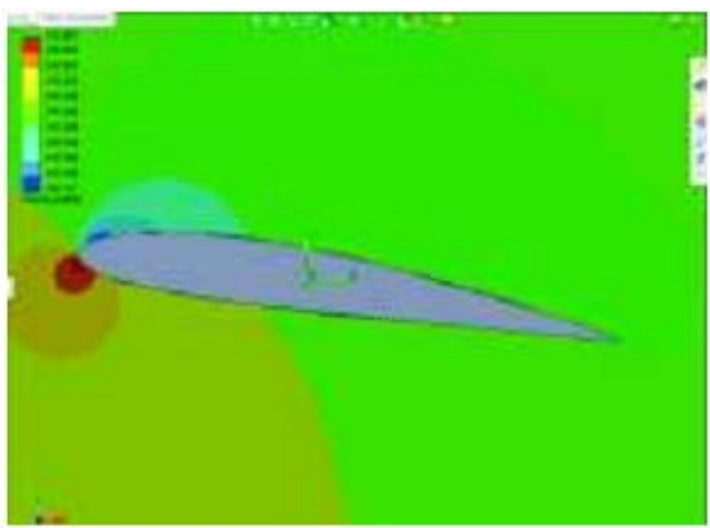

Gambar 13 Kontur sebaran tekanan pada sudut serang $9^{\circ}$

\section{Hasil Simulasi pa da Sudut Serang $\mathbf{1 2}^{\circ}$}

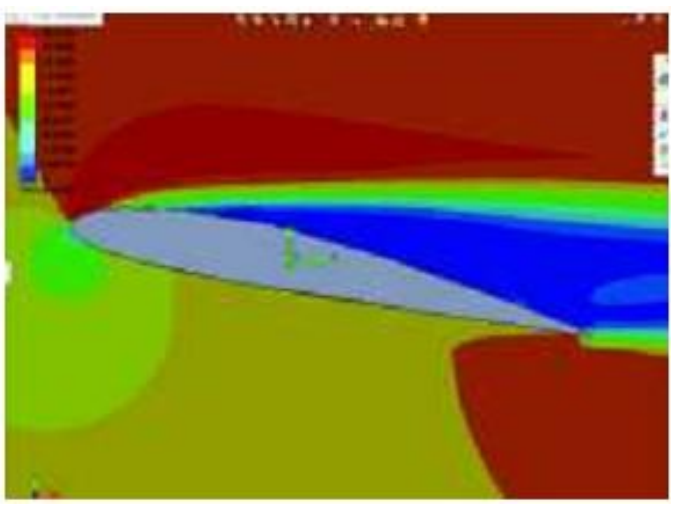

Gambar 14 Kontur sebaran kecepatan pada sudut serang $12^{\circ}$ 


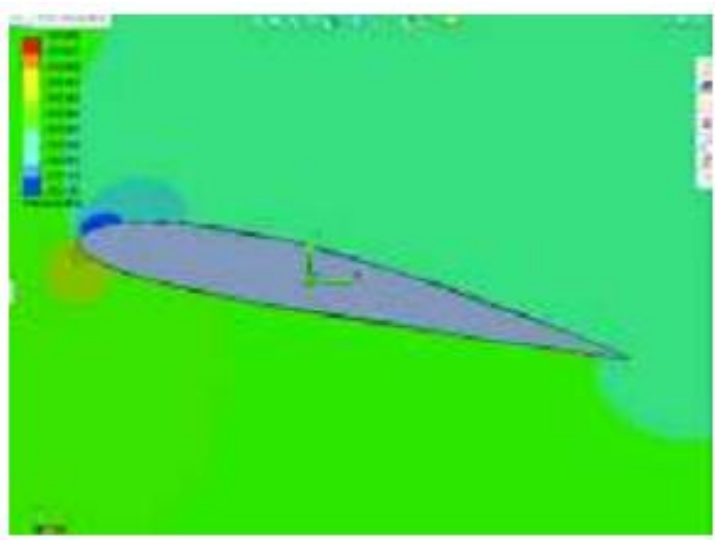

Gambar 15 Kontur sebaran tekanan pada sudut serang $12^{\circ}$

\section{Hasil Simulasi pada Sudut Serang $15^{\circ}$}

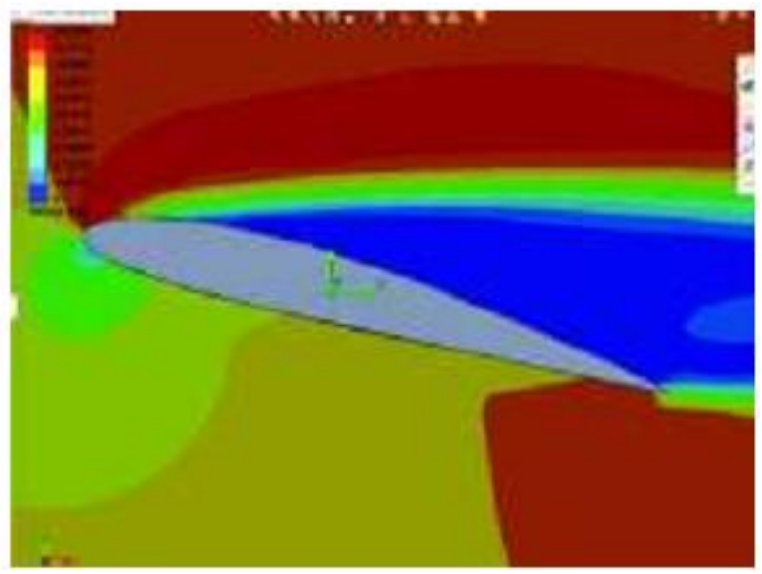

Gambar 16 Kontur sebaran kecepatan pada sudut serang $15^{\circ}$

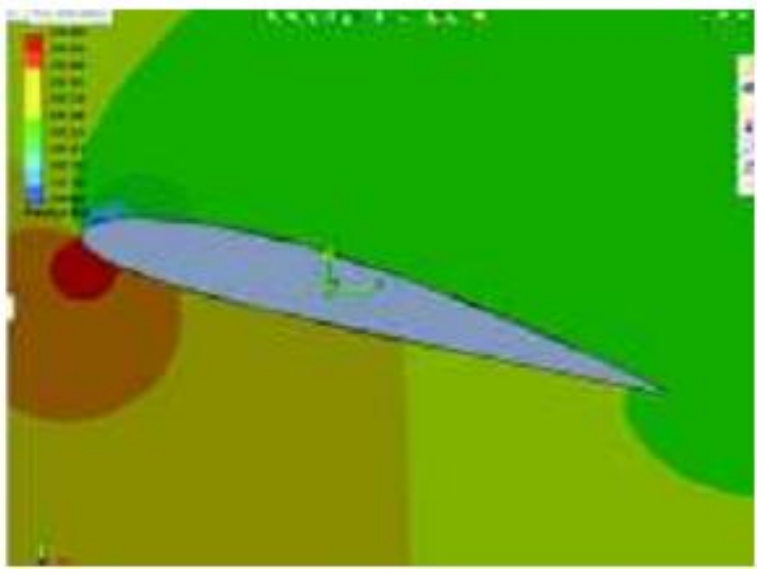

Gambar 17 Kontur sebaran tekanan pada sudut serang $15^{\circ}$ 


\section{Tabulasi Nilai-nilai Hasil Simulasi}

Tabel 3 Tabulasi nilai kecepatan dan tekanan rata-rata

\begin{tabular}{|c|c|c|c|c|}
\hline \multirow{2}{*}{$\begin{array}{c}\text { Sudut } \\
\text { Serang }\end{array}$} & \multicolumn{2}{|c|}{$\begin{array}{c}\text { Kecepatan } \\
\text { Rata-Rata }\end{array}$} & \multicolumn{2}{c|}{ Tekanan Rata-Rata } \\
\cline { 2 - 5 } & $\begin{array}{c}\text { Atas } \\
(\mathbf{m} / \mathbf{s})\end{array}$ & $\begin{array}{c}\text { Bawah } \\
(\mathbf{m} / \mathbf{s})\end{array}$ & Atas $(\mathbf{P a})$ & $\begin{array}{c}\text { Bawah } \\
(\mathbf{P a})\end{array}$ \\
\hline 0 & 10.474 & 13.966 & 101352.7 & 101352.7 \\
\hline 3 & 11.863 & 13.125 & 101337.6 & 101403 \\
\hline 6 & 12.867 & 10.075 & 101262.4 & 101409 \\
\hline 9 & 12.572 & 12.412 & 101242 & 101380.4 \\
\hline 12 & 12.110 & 12.075 & 101254 & 101395 \\
\hline 15 & 11.466 & 12.383 & 101232.7 & 101386.7 \\
\hline
\end{tabular}

Dari tabel diatas dapat dibuat menjadi sebuah grafik kecepatan rata-rata vs sudut serang seperti yang terlihat pada gambar dibawah ini :

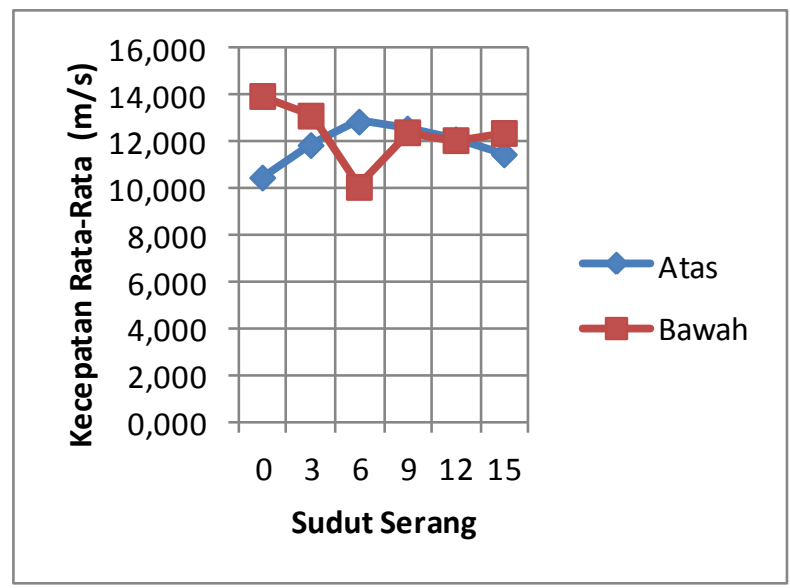

Gambar 18 Grafik kecepatan rata-rata terhadap Sudut serang

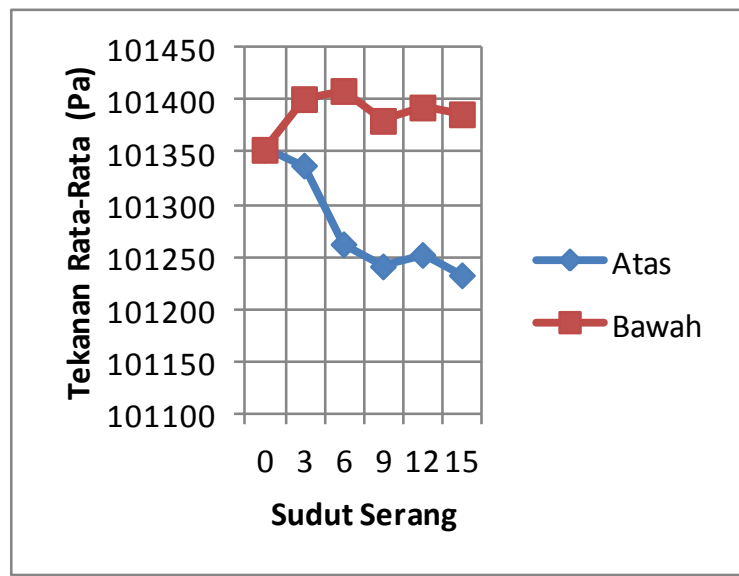

Gambar 19 Grafik tekanan rata-rata terhadap Sudut serang 
Tabel 4 Nilai-Nilai Lift dan Drag

\begin{tabular}{|c|c|c|}
\hline $\begin{array}{c}\text { Sudut } \\
\text { Serang }\end{array}$ & $\mathbf{C}_{\mathbf{L}}$ & $\mathbf{C}_{\mathbf{D}}$ \\
\hline 0 & 0.097 & 0.014 \\
\hline 3 & 0.258 & 0.017 \\
\hline 6 & 0.407 & 0.028 \\
\hline 9 & 0.465 & 0.08 \\
\hline 12 & 0.514 & 0.071 \\
\hline 15 & 0.478 & 0.059 \\
\hline
\end{tabular}

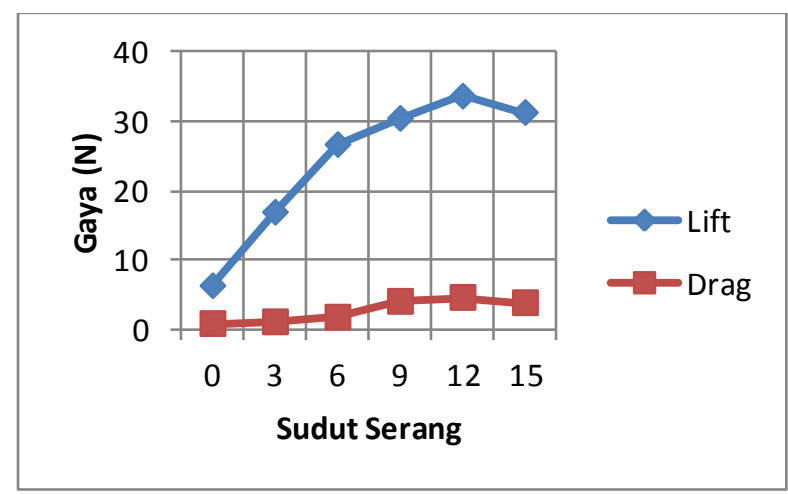

Gambar 20 Grafik Lift dan Drag

Tabel 5 Tabulasi nilai $C_{L}$ dan $C_{D}$

\begin{tabular}{|c|c|c|}
\hline $\begin{array}{c}\text { Sudut } \\
\text { Serang }\end{array}$ & Lift (N) & Drag (N) \\
\hline 0 & 6.217 & 0.763 \\
\hline 3 & 16.817 & 1.010 \\
\hline 6 & 26.579 & 1.684 \\
\hline 9 & 30.350 & 3.966 \\
\hline 12 & 33.553 & 4.535 \\
\hline 15 & 31.193 & 3.771 \\
\hline
\end{tabular}

Dan berikut ini adalah grafik lift coefficient $\left(C_{L}\right)$ vs sudut serang (Angle of Attack) dan grafik drag coefficient $\left(C_{D}\right)$ terhadap sudut serang. 


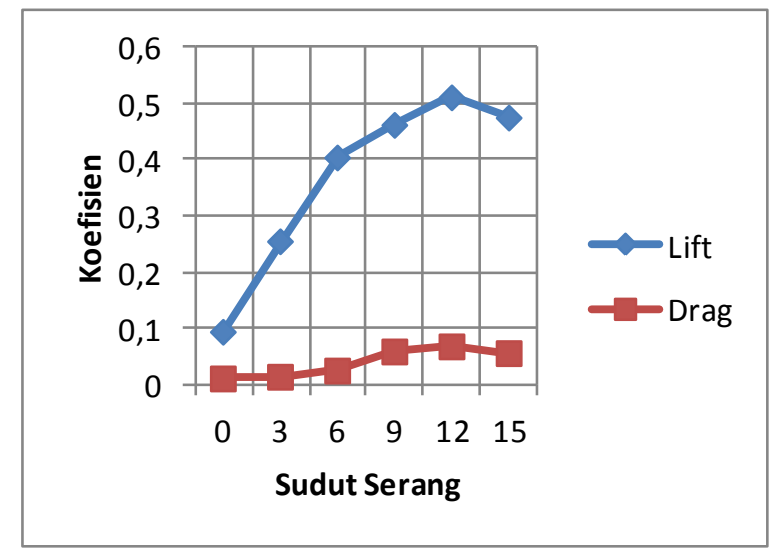

Gambar 21 Grafik $C_{L}$ dan $C_{D}$ terhadap sudut serang

\section{KESIMPULAN DAN SARAN}

\section{Kesimpulan}

1. Dari hasil simulasi, untuk penggunaan airfoil NACA 0021 pada sayap pesawat terbang, untuk sudut serang $3^{\circ}, 6^{\circ}, 9^{\circ}, 12^{\circ}$, dan $15^{\circ}$, maka rata-rata tekanan fluida yang mengalir dipermukaan atas airfoil lebih rendah bila dibandingkan dengan ratarata tekanan dipermukaan bawah airfoil, dan untuk sudut serang $0^{\circ}$ rata-rata tekanan fluida yang mengalir dipermukaan atas airfoil sama dengan rata-rata tekanan dipermukaan bawah airfoil.

2. Dari hasil simulasi, untuk penggunaan airfoil NACA 0021 pada sayap pesawat terbang, untuk sudut serang $6^{\circ}, 9^{\circ}$, dan $12^{\circ}$, maka rata-rata kecepatan fluida yang mengalir dipermukaan atas airfoil lebih tinggi bila dibandingkan dengan rata-rata kecepatan dipermukaan bawah airfoil. Tetapi untuk sudut serang $0^{\circ}, 3^{\circ}$ dan $15^{\circ}$ ratarata kecepatan fluida yang mengalir dipermukaan atas airfoil lebih rendah bila diband ingkan dengan rata-rata kecepatan dipermukaan bawah airfoil.

3. Dari hasil simulasi juga dapat dilihat bahwa dengan variasi sudut serang $0^{\circ}, 3^{\circ}, 6^{\circ}, 9^{\circ}$, $12^{\circ}$, dan $15^{\circ}$, maka semakin besar sudut serang yang diberikan, maka gaya angkat yang dihasilkan juga semakin besar sampai maksimum pada sudut serang $12^{\circ}$. Dan gaya angkat maksimum terjadi pada sudut serang $12^{\circ}$ yaitu sebesar 33,553 $\mathrm{N}$.

\subsection{Saran}

1. Diharapkan untuk penelitian selanjutnya lebih bervariasi dalam hal parameterparameter aerodinamika yang akan dikaji, dan lebih bervariasi juga dalam penentuan variabel bebas dari penelitian.

2. Diharapkan untuk orang-orang yang berkecimpung di dunia aeromodelling agar lebih memperhatian kajian-kajian seperti penelitian ini, agar kedepannya dalam hal pembuatan pesawat model dapat lebih efisien dan ekonomis. 
3. Pemilihan design airfoil sesuai standar NACA juga bisa sebagai kreatifitas dalam variasi dan modifikasi airfoil sayap pesawat terbang sehingga dimungkinkan pengembangan model sayap pesawat yang lebih maksimal dan tepat dalam pemilihan designnya.

\section{DAFTAR PUSTAKA}

[1] Anderson, Jhon D., Jr., 2001, Fundamentals of aerodinamics, McGraw-Hill Book Company, Boston.

[2] Peube, J.L., 2008, Fundamentals of fluid Mechanics and Transport Phenomena, British Library.

[3] Lennon, Andy, 2005, RC Model Aircraft Design, Air Age Media Inc., United State of America.

[4] Munson, Bruce R., 2004, Mekanika Fluida, Edisi Keempat, Erlangga, Jakarta.

[5] Katz, Joseph, 2010, Introductory Fluid Mechanics, Cambridge University Press, United Stateof of America.

[6] Bird, R. Byron, 2007, Transport phenomena, John Wiley and Sons, Inc., United State of America. 